\title{
Difficulty of the ethical decision-making process in withholding and withdrawing life-sustaining treatments in French EDs during COVID pandemic
}

\author{
Marion Douplat ${ }^{1,2^{*}}$ D, Laurent Jacquin ${ }^{3}$, Soizic Frugier ${ }^{1}$, Karim Tazarourte ${ }^{3}$ and Pierre Le Coz ${ }^{2}$
}

France is one of the most impacted countries in the world by the COVID-19 pandemic, with more than 170, 000 confirmed cases. Thus, one of the ethical dilemmas faced by French emergency physicians concerns the decision of withholding or withdrawing life-sustaining treatments, especially given the impact of the COVID19. What's more, we have already shown, prior to the outbreak of COVID-19, that the decision-making process of these decisions is especially difficult in the context of emergency medicine because of the lack of time and the absence of anticipation in chronic diseases [1]. In the context of COVID-19, healthcare teams face several challenges with the decisions to withhold or withdraw life-sustaining treatments.

The first challenge is the fair allocation of medical resources depending on the area of France. Indeed, the Great East region, which was hit first by the pandemic, was the most impacted because of a shortage of critical care beds. The other regions were able to get organized in time and increased their ICU bed capacity. Several recommendations have since been proposed, setting the respect of ethical values and the necessity to treat people equally as a priority [2].

The second challenge is the communication between healthcare teams and relatives. We showed that healthcare teams expressed difficult experiences regarding the announcement and the communication with the patients

\footnotetext{
* Correspondence: marion.douplat@chu-lyon.fr

${ }^{1}$ Emergency Department, Lyon Sud Hospital, University Hospital, Hospices Civiles of Lyon, 165 chemin du Grand Revoyet, F-69495 Pierre Bénite, France 2UMR ADéS 7268, Aix-Marseille University/ EFS / CNRS, Espace éthique méditerranéen, Timone Adulte's Hospital, Marseille, France

Full list of author information is available at the end of the article
}

and their relatives concerning these decisions [3]. Moreover, we found that relatives suffered after a decision of withdrawing or withholding life-sustaining treatments and displayed symptoms of anxiety and depression, which persisted over time [4]. During the COVID-19 pandemic, the relatives were not physically present in EDs because of the ban on hospital visits. Therefore, lots of announcements were made by phone and may have induced additional trauma, given that relatives were not able to accompany their loved ones.

The third challenge we identified is the impact of these decisions on the healthcare teams. We found in a previous study that the decision-making process to withhold or withdraw life-sustaining treatments often triggers a feeling of isolation and being overwhelmed among ED physicians. Mental health issues have been reported among healthcare workers, especially for those who were directly engaged in the care of patients with COVID-19 [5], but no data was available concerning the impact of the decisions to withhold or withdraw life-sustaining treatments. Training healthcare teams to develop an effective communication strategy in the context of a pandemic is a fundamental step in preventing stress disorders, and must be evaluated for improvement.

\section{Acknowledgements \\ We thank Ashley Doerwald and Benjamin Douplat for the English proofreading of the manuscript.}




\section{Funding}

There is no financial support for the investigation or manuscript

development.

\section{Competing interests}

The author(s) declared no potential conflicts of interest with respect to the research, authorship and/or publication of this article.

\section{Author details}

${ }^{1}$ Emergency Department, Lyon Sud Hospital, University Hospital, Hospices Civiles of Lyon, 165 chemin du Grand Revoyet, F-69495 Pierre Bénite, France. ${ }^{2}$ UMR ADéS 7268, Aix-Marseille University/ EFS / CNRS, Espace éthique méditerranéen, Timone Adulte's Hospital, Marseille, France. ${ }^{3}$ Emergency Department, Édouard-Herriot Hospital, Lyon University Hospital, Hospices Civiles of Lyon, 5 place d'Arsonval, F-69003 Lyon, France.

Received: 7 July 2020 Accepted: 28 July 2020

Published online: 13 August 2020

\section{References}

1. Douplat M, Berthiller J, Schott AM, Potinet V, Le Coz P, Tazarourte K, et al. Difficulty of the decision-making process in emergency departments for end-of-life patients. J Eval Clin Pract. 2019;25:1-7.

2. Emanuel EJ, Persad G, Upshur R, Thome B, Parker M, Glickman A, Zhang C, Boyle C, Smith M, Phillips JP. Fair allocation of scarce medical resources in the time of Covid-19. N Engl J Med. 2020:382(21):2049-55.

3. Douplat M, Fraticelli L, Claustre C, Peiretti A, Serre P, Bischoff M, Jacquin L, Freyssenge J, Schott AM, Tazarourte K, Frugier S, Khoury CEL, LAT group. Management of decision of withholding and withdrawing life-sustaining treatments in French EDs. Scand J Trauma Resusc Emerg Med. 2020;28(1):52.

4. Douplat M, Masbou H, Tazarourte K, Berthiller J, Potinet V, Le Coz P, Schott $A M$, Jacquin L. Symptoms of anxiety and depression in relatives after decisions of withholding and withdrawing life-sustaining treatments in emergency departments. Eur J Emerg Med. 2020. https://doi.org/10.1097/ MEJ.0000000000000669.

5. Lai J, Ma S, Wang Y, et al. Factors associated with mental health outcomes among health care workers exposed to coronavirus disease 2019. JAMA Netw Open. 2020;3(3):e203976.

\section{Publisher's Note}

Springer Nature remains neutral with regard to jurisdictional claims in published maps and institutional affiliations.

Ready to submit your research? Choose BMC and benefit from:
- fast, convenient online submission
- thorough peer review by experienced researchers in your field
- rapid publication on acceptance
- support for research data, including large and complex data types
- gold Open Access which fosters wider collaboration and increased citations
- maximum visibility for your research: over 100M website views per year
At BMC, research is always in progress.
Learn more biomedcentral.com/submissions

